\title{
The costly hydroxychloroquine battle in Brazil
}

\section{Felipe Nogueira ${ }^{1}$ (1) Josikwylkson Costa Brito² (1)}

${ }^{1}$ Corresponding author. PhD in Medical Science (Rio de Janeiro). Rio de Janeiro, Brazil. felipenogueira@gmail.com ${ }^{2}$ Centro Universitário UNIFACISA (Campina Grande). Paraíba, Brazil. josikwylkson99@gmail.com

Covid-19 was first identified last November in China and now has spread all over the world. As a new viral illness, despite the standard of care, it has yet no specific treatment.

On March 16th, Didier Raoult, an infectious disease specialist from France, coordinated a study published first as a preprint ${ }^{1}$. Despite not being the first paper that suggested hydroxychloroquine benefits for Covid-19, it created a big turmoil, especially after it was promoted by President Trump on social media.

In Brazil, hydroxychloroquine was the center of a political dispute created by disagreements between President Jair Bolsonaro and Luiz Mandetta, Brazil's Minister of Health when Covid-19 reached the country. Mandetta, following the recommendations from the World Health Organization, made statements in favor of social distancing and quarantine, another point of disagreements with Bolsonaro. As a result, Mandetta was fired. His successor, Nelson Teich, resigned for similar reasons before completing one month in the job.
Almost three months after Raoult's paper was published, the battle around hydroxychloroquine is still very much alive in Brazil. On May 20th, the Ministry of Health - with an interim Minister in charge - published a new protocol for using hydroxychloroquine in the public health system for patients with Covid-19. The previous recommendation, which allowed the use of hydroxychloroquine with azithromycin in hospitalized patients, had now been revised and changed to also permit the use for mild cases. It remains a mystery who is the medical or scientific team responsible for these recommendations, since nobody has signed the document.

The fact that Raoult's article made such noise among the general public and the media is understandable, but the medical community should have not followed the hype. The paper had easily identifiable flaws, like a small sample and lack of randomization. Even though the primary outcome was time to negative viral conversion, viral load or presence was not properly measured in many of the control patients. Maybe worst of all, six patients in the treatment group - of whom one died - were excluded from the analysis. 
The history of medicine reminds us of important lessons that can be applied here. In 1998, an article ${ }^{2}$ published by Andrew Wakefield suggested that the MMR vaccine caused autism. Although it was a small case-series of twelve children, the public reaction to it has consequences up to this today. Raoult's paper caused a public reaction that was similar to Wakefield's, but it impacted even health professionals.

In the 1980s, antiarrhythmic drugs, such as flecainide and encainide, were prescribed to avoid ventricular premature depolarizations after myocardial infarction. There was much more plausibility for treating myocardial infarction with antiarrhythmics than hydroxychloroquine for Covid-19, which has a fragile plausibility ${ }^{3}$. Moreover, through electrocardiograms, doctors could confirm if antiarrhythmics were avoiding arrhythmias. Both electrocardiogram and time to negative viral conversion are surrogate outcomes. It is not yet known whether the Covid-19 patients who improved have faster time to negative viral conversion.

The discussion also involves ethical issues. In Raoult's view, randomized trials are unethical in the context of infectious diseases ${ }^{4}$. Likewise, many physicians of the past considered unethical to test antiarrhythmic drugs in randomized trials ${ }^{5}$. Then, published in 1991, the CAST trial ${ }^{6}$ has shown that antiarrhythmic drugs were not a lifesaver, but rather these drugs increased mortality.

In a disease that most survive like Covid-19, we need randomized controlled trials to give us the answer of whether a drug does treat the disease. As CAST has shown, a drug can be worse than the disease it tries to treat - it is estimated that up to 50,000 Americans died each year in the United States due to antiarrhythmic drugs ${ }^{\mathrm{p}}$. We should never forget CAST's lessons - it is not only ethical to randomize patients; it is unethical not do so, as it can be a lifesaver.

The hydroxychloroquine story gained another chapter with a publication in the Lancet ${ }^{8}$. The study with 96,000 Covid-19 patients reported that antimalarial drugs, with or without macrolide, increased mortality by at least $30 \%$. As it is observational study, confounding factors, such as by indication, might also explain the increase in mortality. Importantly, several researchers wrote their concerns regarding the study's data ${ }^{9}$ and the article was later retracted ${ }^{10}$.
Results from randomized trials are also being released. Hydroxychloroquine was not effective for Covid-19 post-exposure prophylaxis 11 and for outpatients with early Covid-1912. Most importantly, it failed to decrease 28-day mortality or hospital stay in patients with Covid-19 in the RECOVERY Trial ${ }^{13}$ (results published in preprint).

The new treatment protocol is a direct consequence of Bolsonaro's demands. One day after the protocol was released, the Federal Government made a post on social media claiming that "hydroxychloroquine is the most effective treatment against coronavirus currently available". After the repercussion, the post was later removed. Bolsonaro's interference is probably bigger than we will ever know. When interviewed by a Brazilian media, Mandetta said Bolsonaro wanted to change hydroxychloroquine's label to include prescription recommendations for Covid-19. Bolsonaro's actions can definitely set precedence - what if Bolsonaro wants in the future to change the guidelines or labels of other treatments based on his opinions alone? We have reasons for concern. In 2016, Bolsonaro was one of the authors of a law project that would allow the delivery of phosphoethanolamine for cancer patients, bypassing the regulatory agency as clinical trials had not been conducted.

In addition, will the political interference and polarized debate mislead Brazilians about upcoming developments, such as other treatment benefits? In the ACTT-1 trial ${ }^{14}$, remdesivir slightly decreased time to recovery in hospitalized Covid-19 patients (from 15 to 11 days). Although the decrease in mortality was nonsignificant and the study was halted early, it offered better evidence than those of hydroxychloroquine, but it had a small repercusion among the public.

While remdesivir is a costly drug for its marginal benefit, new published results of the RECOVERY trial ${ }^{15}$ showed a really life-saving and inexpensive drug. Low-dose of dexamethasone compared to usual care decreased 28-day mortality in Covid-19 patients requiring ventilation ( $29 \%$ vs $41 \%)$ and in patients receiving oxygen ( $23 \%$ vs $26 \%$ ), without benefit for patients not requiring oxygen support.

We hypothesize that had the medical community at large behaved more skeptically towards hydroxychloroquine extraordinary claims - born from 
Raoult's paper but heavily promoted by media, some physicians, and politicians - we could have handled the pandemic better, focusing on more important aspects, such as testing, contact tracing, and isolation. As of July 22th, Brazil has the second highest number of cases and number of deaths and it is the leading country in new deaths. However, according to the World O Meters website, the country has made about 23,000 tests per million, which places it below the 105th position. Besides, the country is already allowing for some activities to return, which might lead to an increase in new cases and deaths.

Brazil is going through a critical situation, in which good science is being annihilated by the current political class. Therefore, a question remains: if the history of medicine, rich as it is, is not enough, how can we vaccinate ourselves to prevent the spread of treatments that are more based on hope, popularity, and politics than evidence?

\section{Author contributions}

All authors participated in the manuscript conception. In agreement, Nogueira $F$ wrote the first draft of the manuscript. Brito JC reviewed and made important intellectual contributions. Both authors read and agreed with the final version.

\section{Competing interests}

No financial, legal or political competing interests with third parties (government, commercial, private foundation, etc.) were disclosed for any aspect of the submitted work (including but not limited to grants, data monitoring board, study design, manuscript preparation, statistical analysis, etc.).

\section{References}

1. Gautret P, Lagier JC, Parola P, Hoang VT, Meddeb L, Mailhe $M$ et al. Hydroxychloroquine and azithromycin as a treatment of COVID-19: results of an open-label non-randomized clinical trial. Int J Antimicrob Agents. 2020:48. doi: 10.1016/j. ijantimicag.2020.105949

2. Wakefield AJ, Murch SH, Anthony A, Linnell J, Casson DM, Malik $M$ et al. Retracted: Ileal-lymphoid-nodular hyperplasia, non-specific colitis, and pervasive developmental disorder in children. Lancet. 1998;351(9103): 637-641. doi: 10.1016/s01406736(97)11096-0
3. Solla DJF. Hydroxychloroquine for the treatment of COVID-19: an approach based on the philosophy of science and heuristics. J Évid-Based Healthc. 2020;2(1). doi: 10.17267/2675-021Xevidence. $\underline{\text { v2i1.2890 }}$

4. Sayare S. He Was a Science Star. Then He Promoted a Questionable Cure for Covid-19. New York Times [Internet]. 2020. Available from: https://www.nytimes.com/2020/05/12/magazine/ didier-raoult-hydroxychloroquine.html

5. Prasad VK, Cifu AS. Ending Medical Reversals:Improving Outcomes, Saving Lives. 1.ed. Baltimore, US: Johns Hopkins University Press; 2015.

6. Echt DS, Liebson PR, Mitchell LB, Peters RW, Obias-Manno D, Barker AH et al. Mortality and Morbidity in Patients Receiving Encainide, Flecainide, or Placebo. The Cardiac Arrhythmia Suppression Trial. N Engl J Med. 1991; 324(12):781-8. doi: 10.1056/ NEJM199103213241201

7. Gøtzsche PC. Deadly medicines and organized crime: how big pharma has corrupted health care. 1.ed. London, UK: Radcliffe; 2013.

8. Mehra MR, Desai SS, Ruschitzka F, Patel AN. Retracted: Hydroxychloroquine or chloroquine with or without a macrolide for treatment of COVID-19: a multinational registry analysis. Lancet. 2020. doi: 10.1016/S0140-6736(20)31180-6

9. Watson J. An open letter to Mehra et al and The Lancet. Zenodo. 2020;22:S0140-6736(20)31180-6. doi: 10.5281/zenodo.3862789

10. Mehra MR, Desai SS, Ruschitzka F, Patel AN. RetractionHydroxychloroquine or chloroquine with or without a macrolide for treatment of COVID-19: a multinational registry analysis. Lancet. 2020. doi: 10.1016/S0140-6736(20)31324-6

11. Boulware DR, Pullen MF, Bangdiwala AS, Pastick KA, Lofgren SM, Okafor EC et al. A randomized trial of hydroxychloroquine as postexposure prophylaxis for Covid-19. N Engl J Med. 2020. doi: 10.1056/NEJMoa2016638

12. Skipper CP, Pastick KA, Engen NW, Bangdiwala AS, Abassi M, Lofgen SM et al. Hydroxychloroquine in Nonhospitalized Adults With Early COVID-19: A Randomized Trial. Ann Intern Med. 2020. doi: $10.7326 / \mathrm{M} 20-4207$

13. Horby P, Mafham M, Linsell L, Bell JL, Staplin N, Emberson JR et al. Effect of Hydroxychloroquine in Hospitalized Patients with COVID-19: Preliminary results from a multi-centre, randomized, controlled trial. MedRxiv. 2020. doi: 10.1101/2020.07.15.20151852

14. Beigel JH, Tomashek KM, Dodd LE, Mehta AK, Zingman BS, Kalil AC et al. Remdesivir for the treatment of Covid-19 - preliminary report. N Engl J Med. doi: 10.1056/NEJMoa2007764

15. The RECOVERY Collaborative Group. Dexamethasone in hospitalized patients with Covid-19 - preliminary report. N Engl J Med. 2020. doi: 10.1056/NEJMoa2021436 